\section{Historier om helse - men ikke helsehistorie}

Natvig JB, Swärd ET, Hem E, red. Historier om helse

187 s, ill. Oslo: Tidsskrift for Den norske legeforening, 2009. Boken kan fås ved henvendelse til Tidsskriftet ISBN 978-82-8070-079-7

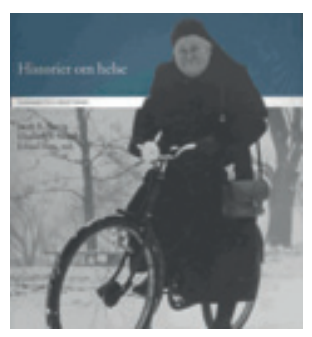

I 1995 oppnevnte Sosial- og helsedepartementet en prosjektgruppe som skulle utrede et nasjonalt medisinsk museum. Forholdene lå da til rette for at et slikt museum

skulle komme i den gamle administrasjonsbygningen på Rikshospitalet i Oslo, det som skulle bli Pilestredet Park. I 1999 sluttet Sosial- og helsedepartementet seg til de overordnede mål som prosjektgruppen hadde kommet frem til. Det var grunn til å se frem til etableringen av et norsk medisinhistorisk museum med røtter i det tidligere Rikshospitalet. Slik skulle det ikke gå. Det kom en politisk snumanøver, og planene om et medisinhistorisk museum ble torpedert. Daværende helsestatsråd besluttet i 2001 å opprette det, ikke som en selvstendig enhet, men som en del av Norsk Teknisk Museum. For å sitere et av kapitlene er «landets eneste nasjonale medisinske museum fremdeles [...] en krok i et teknisk museum» (s. 166).

For å bøte på skaden, og gjøre det beste ut av situasjonen, ble Stiftelsen Nasjonalt Medisinsk Museum etablert i 2002. Stiftelsen utviklet nokså snart et godt samarbeid med det nyetablerte medisinske museet, der den bl.a. tok sikte på å organisere faglige seminarer og mobile utstillinger. At Stiftelsen etter hvert fikk kontorer i den gamle Kvinneklinikken på Rikshospitalet kom som en ikke planlagt bonus.

Denne boken er på mange måter et produkt av Stiftelsens arbeid. Den faller i tre deler. Den største delen er Helsehistoriske gløtt, som kan knyttes til tidligere seminarer som Stiftelsen har arrangert. Neste del er kalt $\AA$ ta vare på kunnskap, der bl.a. Ole Didrik Lærum forteller om å bo i et hjem som etter hvert fikk et musealt preg, og som nå er registrert som medisinhistorisk samling. Den siste delen, Fremtidens museum, er den korteste, og her rettes søkelyset bl.a. mot de store utfordringene innen museumsvesenet.

Dette er en skattkiste med historier, mange av dem perler som det er vanskelig å finne andre steder. Her er meget viktige kapitler, som Aina Schiøtz' dramatiske beretning om barnemordene i Norge som bidro til, og delvis preget, utviklingen av spesialiteten rettsmedisin, en fortelling som trekker litterære linjer fra dikteren Christian Braunmann Tullin (som var borgermester i Christiania) til Henrik Wergeland.

Det er ikke alltid lett å finne biografier til enkelte personer i det medisinhistoriske miljø i Norge. Kapitlet om Alette Schreiner, som til en viss grad kom i skyggen av sin berømte mann anatomen Kristian Schreiner, vil ikke minst være verdifullt for leger som har hatt sin anatomiundervisning i de gamle lokalene i Karl Johans gate. Og kapitlet om vår store radiokjemiker Ellen Gleditsch, som bygger på Annette Lykknes' doktoravhandling fra 2005, er meget leseverdig og forteller om den sosiologiske utviklingen for kvinnelige forskere i det 20. århundre. Else-Britt Nilsens beretning om nonnenes innsats i det norske helsevesenet føyer seg fint sammen med Jorunn Mathisens artikkel om sykepleiens utvikling.

Dette er ingen samlet oversikt over helsevesenets historie i vårt land. Men det er en samling historier fra ulike deler av vår medisinske historie. Den har bredt siktemål og vil finne lesere blant alle med interesse for utviklingen av vårt helsevesen.

\section{Johan A. Aarli}

Bergen

\section{Evolusjonens ti store oppfinnelser}

Lane $\mathrm{N}$.

\section{Life ascending}

The ten great inventions of evolution. 344 s, ill. London: Profile Books, 2009

Pris GBP 10

ISBN 978-1-86197-8189

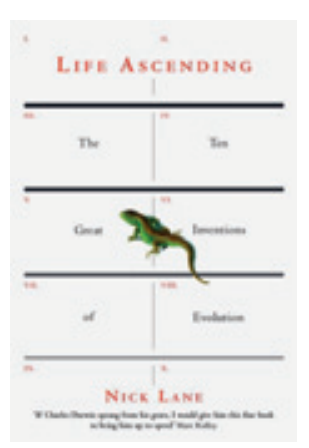

I Life ascending har den engelske biokjemikeren Nick Lane en original tilnærming til temaet livets opprinnelse og utvikling. Han beskriver og kommenterer ikke bare konvensjonelle teorier om evolusjonen som

mange har gjort, men gir oss innsikt i livets egen oppfinnsomhet for å forstå livets utvikling på jorden. Han tar utgangspunkt i det han kaller ti nøkkeloppfinnelser i evolusjonen. Han har lagt følgende kriterier til grunn for sine valg: oppfinnelsen må ha revolusjonert den levende verden, være av den største betydning i dag, være direkte følge av naturlig seleksjon, ha ikonstatus og at den fascinerer ham. Han argumenterer godt for sine valg: livets begynnelse, DNA,

fotosyntesen, den komplekse cellen, seksualitet, bevegelse, syn, varmt blod, bevissthet og død. Han gir oss innsikt bl.a. $i$ livets begynnelse, livets endringer og hva som betinger utvikling til et komplekst liv. Likeledes hvordan vi har ervervet oss innsikt i og kunnskap om evolusjonen. Her gis en god og nyttig repetisjon av den innsatsen innflytelsesrike forskere har bidratt med.

Boken er ikke skrevet for fagfolk, men popularisert slik at den blir tilgjengelig for de fleste uten å gå bekostning av faglig kvalitet. Den er en fryd å lese. Han skriver godt, faglig, begeistret, morsomt og tankevekkendeog stiller overraskende spørsmål.

Innledningsvis stusset jeg over hans ti valg. Jeg kunne tenkt meg andre kandidater. Hvordan kan døden være en viktig oppfinnelse? Hvorfor må organismer dø, burde ikke evolusjonen søke å bevare livet? Nick Lane gir svar i boken, som anbefales alle som er interessert i evolusjonen.

\title{
Berit Rostad
}

Institutt for samfunnsmedisin

Norges teknisk-naturvitenskapelige universitet Trondheim

\section{Finansfyrste og statsminister}

Frydenlund B.

Stormannen Peder Anker

En biografi. 398 s, ill. Oslo: Aschehoug, 2009.

Pris NOK 449

ISBN 978-82-03-21084-6

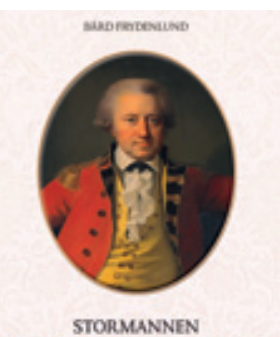

PEDER ANKER
Forfatteren sier i sitt etterord at han ønsker boken skal være til nytte og glede for «faghistorikere og generelt historieinteresserte lesere». Denne anmelder prøver $i$ all beskjedenhet å anse seg som tilhørende den siste gruppen. For meg har forfatteren bare delvis nådd sitt mål. Peder Anker (1749-1824), kammerherren på Bogstad, generalveiintendanten og den første statsministeren i Stockholm etter 1814 , er en person som etterlater seg mye i norsk historie. Kollega Per Holck skrev for noen år siden en meget leseverdig biografi om hans eldre og mer fargerike bror, Bernt (1). Peder var nok en mer formell person, men skapte vel så mye gjennom sine investeringer i jordbruk, skogbruk og sager, gruver og jernverk. I tillegg spilte han en betydelig rolle under begivenhetene i 1814 og ble altså Norges første statsminister under unionen med Sverige. 